\author{
T.S. Udartseva ${ }^{1, *}$, C. DeVeroux ${ }^{2}$, N.V. Druzhinina ${ }^{1}$ \\ ${ }^{1}$ Karagandy University of the name of academician E.A. Buketov, Kazakhstan; \\ ${ }^{2}$ University of Connecticut, USA \\ (E-mail:tamaraud@mail.ru)
}

\title{
Ways of world experience in flipped learning implementation for foreign language training
}

\begin{abstract}
Inthearticletheauthorsconsiderthe concept of flipped learning method, its features and constituent components.Flippedlearning (FL) is a pedagogical method aimed at traditional education system transformation. FL method implies the shift of activities performed in group and in individual space (activities previously done in class, now students do outside of class). Due to insufficient level FL application study in homeland education system, authors focused on studying of FL effectiveness in the process of English language teaching as a foreign language at universities of 5 countries: Russia, Egypt, Ecuador, Thailand and Indonesia. The universities selection for study was carried out according to such criteria as: level of education, English language study as a foreign language, FL elements implementation in students training, using feedback at the end of the course study.According to the carries out analysis, all participants of educational process demonstrated positive attitude to FL use at5 universities, among leading positive points were mentioned the following: improvement in language proficiency level, increase in the level of students'independent work in organizing their studies, possibility of digital technologies wide implementation in educational process.As the results of performedanalysis at foreign universities in the field of FL method implementation in language training, the authors carried out SWOT analysis, which makes it possible to determine presence of opportunities, difficulties and threats for FL implementation in the process of foreign language training at homelanduniversity.
\end{abstract}

Keywords: foreign language, flipped learning, individual space, group space, SWOT-analysis, digital platform, active learning methods, traditional system of education.

\section{Introduction}

In modern education system, changes in applied teaching methods aredetermined by new conditions of social and economic changes affecting graduates' requirements of higher educational institutions. Today society needs competitive highly qualified specialists in labor market, and above all, striving for continuous personal and professional development. The existing education system tends to shift its focus from «learning for life» to the concept of «lifelong learning», since graduates of higher educational institutions should, first of all, be focused not on passive knowledge acquisition, but on practical ability to find, analyze and receive information at any time convenient for them and in at any convenient place [1]. According to G. Fischer, modern education should not have space and time limitations, because «lifelong learning» concept should be the main motivation for modern student of higher education[2].

In system of non-linguistic university students' language training, there is a significant gap between the requirements of educational institutions regulatory documents and traditional approach to foreign language teaching [3], thus, there is a need to modernize traditional system of students' foreign language training at universities.

Pedagogical community is searching for new educational technology that can transform both teacher's and students' role, in order to increase foreign language learning effectiveness by the use of information technology [4-7].

In our opinion, solution for this question can be the introduction of FL method in foreign language education. In today's realities, FL method is gaining popularity around the world in all areas of educational space, including the field of foreign language training. This method provides teachers and students with freedom in foreign language teaching and learning, because everyone becomes an active participant of educational process.

FL was first discussed in 2007, when two Colorado Chemistry teachers J. Bergman and A. Sams [8] recorded teaching materials and posted them on Youtube channel for students who were absent from class.

\footnotetext{
${ }^{*}$ Corresponding author's e-mail: tamaraud@mail.ru
} 
As a result of using this form of work, both teachers and students noticed significant improvements in information perception and understanding by students: an increased degree of active interaction between teachers and students, as well as between students during classroom sessions. Thus, this event was an active introduction of FL method into educational process.

Based on J. Bergman and A. Sams concept, flipped classroom technology is conditions when «... what was usually done in classroom, under these conditions is performed at home, and what was previously done at home is now performed in the classroom...»[8], thus this method turns over traditional learning system.

However, we can say that this definition is incomplete, since it reflects only partially concept of «flipped learning». The principle of FL application is not only in didactic content and providing students with video materials before the lesson, but also it implies redistribution of lesson organization. According to M.V. Simonova, main distinctive feature of FL class from traditional class is «cognition and learning process transferring to independent work outside the classroom, so it helps to save class time and to deepen knowledge and material understanding directly in classroom» [9]. But this definition also does not give a complete representation and does not reveal the concept of FL.

In 2017, professor Robert Tolbert modified and expanded the definition of FL concept, it revealed its new special meaning and significance:» Flipped Learning is a pedagogical approach when first contact with new material is shifted from group educational space to personal space in the form of structured assignments, and as a result, group space is transformed into a dynamic, interactive educational environment where teacher guides students as they apply acquired knowledge and involves them in an active educational process» [10].

During this period, there are still no standards for FL definition and application, thus, in 2018, nonprofit organization Academy of active learning arts and sciences (AALAS) set asits goal complementing and standardizing definitions for concept of «flipped learning». Taking into account the existing experience, a group of researchers from leading universities in the world proposed the following definition of flipped learning method: «Flipped learning is a technique that gives teacher an opportunity to «reach every student». The flipped learning technique «flips» traditional class by introducing new material before class, thus giving teacher an opportunity to use class time to actively interact with each student through interactive assignments». The key factor that reveals main idea of this method is the phrase «reach every student», and this is where the concept of the flipped class method is. According to educators-scientists, the use of FL method gave the meaning to the concept of «learner-centered approach», from that moment it became really possible [11-13]. Shari Kendrick, a San Antonio teacher, best defined the teacher's role in FL: «I don't have to go to class and explain the same material five times a day. Instead, I spend my day interacting with and helping my students».

Considering the proposed definitions, it should be noted that in modern pedagogical science there is no clear definition of FL as condition or as approach.

As it can be seen from the definition of this concept, proposed by its founders J. Bergman and A. Sams, initially by FL they meant educational environment creation for studying the offered material. But in the process of this concept development, an expansion of its categories is observed and it can no longer be said that it refers only to the circumstances creation for learning. Thus, based on later definitions, it is clear that FL refers to both cognitive process organization, and to high-quality content creation, and to student's development as personality, and to participants interaction in the educational process to achieve a specific goal.

In our opinion, FL cannot be referred to the category «approach», since the concept of «approach» is used in cases when there is no solution to the problem and only the search for approaches to the problem itself is being carried out. According to E.I. Purgina, method in contrast to the approach «... characterizes cognition process from the point of view of determining the way of its implementation, way of subject's activity in cognition». The approach is a platform for methods and principles formation [14]. Based on this definition, we cannot say that FL is not an objective that does not have ways of its solving and implementing, therefore we reject category of «approach».

In our work, we classify FL as a method based on the following views. As I. Ya. Lerner states, «method is a way to achieve learning objectives, which is a system of teacher's consistent and orderly actions who organizes with the help of certain means students' practical and cognitive activities to assimilate social experience» [15]; according to Yu.K. Babanskiy definition, «method is a way teacher and students orderly interconnected activity aimed at solving educational objectives» [16]; I.F. Khomkiy gives the following definition of the concept: «teaching methods should be considered as methods of teacher's teaching activity and students' 
educational and cognitive activities organization to solve various didactic tasks aimed at mastering material being studied» [17].

To sum up the definitions of the concept «method», despite the differences presence, it is necessary to note some common features that unite these definitions, these include — solving problems and achieving learning objectives, mastering educational material and presence of interaction between participants of educational process. In our opinion, these are features that allow us to classify FL as method of educational activities organization.

Concluding all of the above, we propose the following definition of FL method: Flipped learning is a new method of teacher's and a student's collaborative activities organization, based on digital technologies active implementation in order to form students' skills of theoretical material primary independent mastering in their personal space, for deeper study, analysis and practical application of the knowledge acquired in group space.

Based on the proposed definition, we can conclude that very important element of FL implementation is the creation of educational space for students to work, both independently and in a group. According to scientists Hamdan N. and McKnight P. [18], for successful FL application in the classroom, it is necessary to follow 4 basic principles:

1. flexible environment- teacher provides student with the right to choose place, time and order of presented material study;

2. learning culture implies student-centered approach predominance in learning process, and teacher acquires the role of mentor, not a translator of knowledge;

3. intentional content -teacher determines the content of educational material and form of its presentation for students, makes it possible to maximize time of studentsэ activity in the classroom. This principle gives teacher opportunity to change the content of material and types of activities at the lesson, depending on students' needs and interests [19];

4. professional educator - increasing teacher's role in educational space organizing. The teacher must have high methodological level to implement FL method. Even though the teacher's role may be minimal in this approach, he plays an important role in making this method work.

Thus, the issue of learning process organization is based on FL method requires special attention and theoretical justification.

\section{Experimental}

The experience of FL method implementation is widely covered in the foreign literature in various fields of educational activity. The issue of FL method implementation in homeland literature, in teaching English as a foreign language, is not sufficiently covered. Therefore, the purpose of this work is to study effectiveness of FL application in foreign language teaching in world universities; strengths and weaknesses identification of this method, as well as consideration of possibilities for its implementation at Kazakhstani university.

To study FL effectiveness application in teaching foreign language at universities around the world, in our work we set the following questions: 1 . What types of activities were used by teachers to implement FL at foreign language classes? 2. What are students' learning outcomes after FL implementation? 3. What is students' and teachers' attitude to FL implementation?

For literature review, we selected materials from search engines such as Research Gate, Google Scholar, Academia.edu. For analysis, 5 articles were selected for the period from 2016 to 2018. The following main criteria were identified for material selection:

1. Stage of study -Bachelor

2. Students studying English as a foreign language

3. FL elements implementation

4. Feedback at the end of the course

To analyze FL application, we selected 5 universities in countries such as Russia, Egypt, Ecuador, Thailand and Indonesia. All studies are devoted to FL application in English of as a foreign language study (Table 1). 
Experience of flipped learning implementation in foreign language training

\begin{tabular}{|c|c|c|c|c|}
\hline Author, year & Participants & Subject & Methods of data collecting & Outcomes \\
\hline $\begin{array}{l}\text { A. Evseeva, } \\
\text { A. Solozhenko, } \\
2015\end{array}$ & $\begin{array}{l}2 \text { year students, } \\
\text { Tomsk Polytech- } \\
\text { nic university }\end{array}$ & $\begin{array}{l}\text { English at tech- } \\
\text { nical university }\end{array}$ & $\begin{array}{l}50 \% \text { of classes are on } \\
\text { Moodle digital platform, } \\
\text { peer-assessment, test, inter- } \\
\text { views }\end{array}$ & $\begin{array}{l}85 \% \text { of students promotes FL } \\
\text { in study, aswellas } 15 \% \text { had } \\
\text { technical problems and prob- } \\
\text { lems with self-organization }\end{array}$ \\
\hline $\begin{array}{l}\text { N.A. Soliman, } \\
2016\end{array}$ & $\begin{array}{l}\text { British University } \\
\text { in Egypt }\end{array}$ & $\begin{array}{l}\text { English for aca- } \\
\text { demic purposes }\end{array}$ & $\begin{array}{l}\text { Articles, teamwork, presen- } \\
\text { tations, discussions, think- } \\
\text { pair-share method, forums, } \\
\text { video records }\end{array}$ & $\begin{array}{l}\text { Language skills improvement, } \\
\text { face-to-face classes were more } \\
\text { effective, } 24 / 7 \text { access to materi- } \\
\text { als }\end{array}$ \\
\hline $\begin{array}{l}\text { L. Melendez, } \\
\text { S. Iza, } \\
2017\end{array}$ & $\begin{array}{l}\text { Technical univer- } \\
\text { sity of Ambato, } \\
30 \text { students of B1 } \\
\text { level }\end{array}$ & English grammar & $\begin{array}{l}\text { Edmodo digital platform, } \\
\text { entry test, end-of-course test }\end{array}$ & $\begin{array}{l}\text { Students' knowledge improve- } \\
\text { ment at } 95 \% \\
\text { Immediate feedback, content } \\
\text { visibility and creativity }\end{array}$ \\
\hline $\begin{array}{l}\text { B.Santikarn, } \\
\text { S. Wichadee, } \\
2018\end{array}$ & $\begin{array}{l}\text { Bangkok Univer- } \\
\text { sity, } \\
40 \text { students }\end{array}$ & $\begin{array}{l}\text { English for ex- } \\
\text { ploring the world }\end{array}$ & $\begin{array}{l}2 \text { assignments, } 3 \text { oral tasks, } \\
\text { questionnaire for determin- } \\
\text { ing students attitude to FL, } \\
\text { questionnaire for determin- } \\
\text { ing students' level of inde- } \\
\text { pendence }\end{array}$ & $\begin{array}{l}\text { Students note improvement in } \\
\text { material perception, increase of } \\
\text { independence level, personal } \\
\text { pace of material study }\end{array}$ \\
\hline $\begin{array}{l}\text { A. Fauzan, } \\
\text { M.N. Ngabut, } \\
2018\end{array}$ & $\begin{array}{lr}\text { University } & \text { of } \\
\text { Palangka } & \text { Raya, } \\
\text { Indonesia, } & \text { stu- } \\
\text { dents of } 4 & \text { semes- } \\
\text { ter }\end{array}$ & $\begin{array}{l}\text { Writing } 3 \text { (Eng- } \\
\text { lish as a foreign } \\
\text { language) }\end{array}$ & $\begin{array}{l}\text { Students questionnaire after } \\
\text { the course study }\end{array}$ & $\begin{array}{l}\text { - independent material study, } \\
\text { - detailed material review at } \\
\text { classroom } \\
\text { - more time for feedback from } \\
\text { the teacher }\end{array}$ \\
\hline
\end{tabular}

A. Evseeva, A. Solozhenko. Use of flipped classroom technology in Language learning. The studying process organization of foreign language was carried out through the use of Moodle digital platform. 50 percent of students' assignments were presented on platform in the form of various activities. While preparation for lesson, students were offered to watch short video lectures containing material for next lesson, they were offered to work with additional online resources and questions were posted for further work in the classroom. The time of the lesson was devoted to clarifying difficult grammatical and lexical issues, making presentations and discussions. After lesson with a teacher, students were asked to evaluate work of their groupmates and test their knowledge on material studied.

As a result of this study, the following advantages and disadvantages were noted. $85 \%$ of students who took part in this experiment spoke positively about FL method use, while remaining $15 \%$ experienced technical problems and difficulties with self-discipline. Almost all students $98 \%$ noted the availability of material 24/7. $75 \%$ of survey participants appreciated possibility of collaboration through online resources [20].

N.A. Soliman. Teaching English for academic purposes via the flipped learning approach.The study was conducted at British University in Egypt in study of «English for specific purposes» discipline. As material for independent work before the lesson, students were offered 10-15 minute interactive videos containing questions of the initial levels of Bloom's taxonomy, task was not evaluated, in order to eliminate fear of not understanding new material. For teacher, these videos are an effective tool for preparing for lesson, as they allow you to find out students' problem areas in new material assimilation before the lesson. At the lesson, students were offered various types of activities aimed at eliminating gaps of independent material study, developing skills in working in pairs/groups, think-pair-share method was used. As tasks for independent work after class, students completed Web-Quest, worked with scientific articles, recorded videos, participated in forums.

This study showed that, in general, both students and teachers have positive attitude towards FL use. Students, on the other hand, note the advantages of studying material online, since in the classroom teacher pays more attention to each student; students talk about significant improvements in proficiency level of foreign language, as this method increases motivation in language learning; possibility of access to educational materials at any time and at any place; interactivity of the studied material was highlighted as main advantage of this method [21]. 
L. Melendez, S. Iza. Application of the flipped classroom methodology in a virtual platform for teaching English language grammar in level B1.The research was conducted in English grammar class among 30 students. The course material was posted on Edmodo digital educational platform, which provides access to information at any time. As a control report, students were offered the same test as entry and end-ofcourse testing. As a result of FL application in experimental group, significant improvements in results of end-of-course testing were revealed, in comparison with the results of entry testing.

Thus, students participating in this study noted the following advantages: repetition, interactivity and creativity of studied material, feedback presence from teacher in the process of material studying. Among the difficulties, students noted that at the beginning of the experiment they were not ready to regularly review material and complete tasks before class [22].

B. Santikarn, S. Wichadee. Flipping the classroom for English language learners: a study of learning performance and perceptions. The purpose of this study was to determine effectiveness of FL application, to identify level of this method perception and activity by students. The study involved 40 students. The collection of material for study was carried out in the form of written and oral assignments, as well as in the form of a questionnaire to determine the method perception.

Having analyzed the data collected, the following results were revealed: with regard to methodological equipment of the course, students were satisfied with material study presented in the form of short lectures posted on a digital platform, in the course of face-to-face studies, students note more attention from teacher to everyone, pace and intensity of the lesson increased, level and quality of students' independent work increased [23].

A. Fauzan, M.N. Ngabut. EFL students' perception on flipped learning in writing classes. The main the authors objective of this study was to study the level of students' readiness to apply FL method. As a methodological material, students were provided with video and text materials for independent study. The method of projects, individual, pair and group writing, and presentations were used as active forms of learning in the classroom. As a final form of information obtaining, students were offered a questionnaire, which reflected their perception of FL implementation.

Based on research results, students noted the following advantages of advanced learning method: possibility of material independent study, which allows you to better focus on material being studied; class time, according to the students, allowed a deeper and more detailed study of material in the process of individual, pair and group forms of work; students note presence of high-quality feedback from the teacher. Overall, $44 \%$ of students were positive about FL using in the course study [24].

\section{Results and Discussion}

Taking into account data from the 5 studies analyzed, we see that in all cases, students' performance in FL groups improved on measurable criteria. In all cases, students demonstrated positive perception FL form of material presentation, way of material study, forms of active learning tasks at the lesson, and presence of feedback from the teacher. These results indicate effectiveness of FL introduction in the process of foreign language training and positive perception of this method by all participants of educational process.

As for the issue of FL introduction at universities in Kazakhstan, and based on the analysis of studied experience among foreign universities, we compiled a SWOT analysis (Table 2) in order to determine the readiness of homeland education system to implement this experience.

SWOT-analysis of flipped learning method implementation

\begin{tabular}{|l|l|}
\hline \multicolumn{1}{|c|}{ Strengths } & \multicolumn{1}{c|}{ Weaknesses } \\
\hline \hline \multicolumn{1}{|c|}{1} & \multicolumn{1}{c|}{2} \\
\hline - saving time in class as a result of material self-study & - significant time spent on material preparation \\
by students outside the classroom; & for the lesson and course «re-planning»; \\
- high level of feedback; & - low level of teachers and students' computer \\
- possibility of student-centered approach implementa- & literacy; \\
tion in training; & - preparation of high-quality electronic content; \\
- implementation of highest levels of Bloom's taxon- & - students'not readiness for independent work; \\
omy in the classroom; & - teachers' bot readinessfor changing their way \\
- increasing the level of students' interaction; & of thinking; \\
\hline
\end{tabular}




\begin{tabular}{|c|c|}
\hline 1 & 2 \\
\hline $\begin{array}{l}\text { - use of active forms of education } \\
\text { - individual pace of study; } \\
\text { - high level of student involvement at the classroom; } \\
\text { - development of students' creative abilities }\end{array}$ & $\begin{array}{l}\text { - lack of technical capabilities when working } \\
\text { with material }\end{array}$ \\
\hline \multicolumn{2}{|c|}{$\begin{array}{l}\text { FL method is an effective tool for student-centered approach implementation to learning, through the use of active } \\
\text { teaching methods during the classroom sessions, through preliminary materials self-study at home. } \\
\text { To implement FL method, all participants of the educational process must be ready to accept new form of teaching } \\
\text { and learning. }\end{array}$} \\
\hline Opportunities & Threats \\
\hline $\begin{array}{l}\text { - full-scale use of available Internet resources for edu- } \\
\text { cational content creation; } \\
\text { - full-fledged opportunity to implement level learning; } \\
\text { - organization and control of students' out of class- } \\
\text { room preparation for lesson; } \\
\text { - ability to instant lesson plan adjust, in order to elimi- } \\
\text { nate gaps in independent material study; } \\
\text { - assessment of students' achievements at each lesson }\end{array}$ & $\begin{array}{l}\text { - not all students performed pre-class assign- } \\
\text { ments; } \\
\text { - lack of students skills self-organization and in- } \\
\text { dependent; } \\
\text { - lack of support from administration and par- } \\
\text { ents' disapproval; } \\
\text { - high organizational skills for working in an in- } \\
\text { dividual space }\end{array}$ \\
\hline
\end{tabular}

After analyzing the table and projecting the data obtained for modern conditions of foreign language teaching, we can conclude that the widespread use of FL method in the process of foreign language learning is not easy and it requires significant efforts from all participants of educational process. One of the most important and time-consuming aspects of FL method is preparation of high-quality educational content, which is not easy even with the modern Internet resources. Moreover, despite the opinion that teacher «leaves the stage», in reality, teacher is now responsible not only for organizing students' work in the classroom, but also he is responsible for students' independent work in an individual space outside the classroom. There are additional opportunities for the teacher to deliver the material in a variety of forms, thanks to the increased time spent in the classroom on active interaction and use of active forms of learning.

The main risks on for students are their unwillingness to actively participate in educational process, their lack of self-organization skills, but in process of independent work with the material and studying it at their own pace, these skills and abilities will be formed, and students will learn to be responsible for their training.

The main advantage for students and extra load for teacher is presence of constant feedback, which gives both teacher and students motivation for constant work and involvement in teaching and learning process.

In general, it is important to emphasize that FL implementation contributes to development of such modern graduate's qualities as motivation for constant self-development, high level of self-organization, increased responsibility for their activities, and ability to work independently. These qualities implementation among students in foreign language classes makes it possible to achieve high results in foreign language education in accordance with homeland and international standards.

In conclusion, we consider it necessary to note that taking into account experience of foreign researchers, identified strengths and weaknesses, risks and threats, we can say that FL method is an effective tool in organization of students' cognitive activity, contributing to formation and improvement of language and professional skills that meet the requirements modern society.

\section{References}

1 Gluchmanova M. Application of e-learning in foreign language teaching at the technical university // Social and Behavioral Sciences. - 2015. - P. 3144-3149. https://doi.org/10.1016/j.sbspro.2015.01.1053.

2 Fischer, G. (2000). Lifelong learning - More than Training // Journal of Interactive Learning Research, 11, 3(4), PP. 265294. 
3 Babic Z. Exploring ESP syllabi: some implications for further pedagogical considerations // Zbornik Instituta za Pedagoska Istrazivanja. - 2016. - Vol. 48, issue 1. — P. 164-179. DOI: http://dx.doi.org/10.2298/ZIPI1601164B.

4 Fredy Geovanni Escobar Fandino, Luz Dary Munoz, Angela Juliette Silva Velandia. Motivation and E-Learning English as a foreign language: A qualitative study // Heliyon. — 2019. - № 5. - P. 1-7. https://doi.org/10.1016/j.heliyon.2019.e02394.

5 Bradac V., Walek B. A comprehensive adaptive system for e-learning of foreign languages // Expert system with applications. — 2017. — Vol. 90. — P. 414-426. https://doi.org/10.1016/j.eswa.2017.08.019.

6 Hubackova S., Ruzickova M. Experience in foreign language teaching with ICT support // Procedia computer science. 2011. - Vol. 3. - P.243-247. https://doi.org/10.1016/j.procs.2010.12.041.

7 Dettori G., Lupi V. ICT and new methodologies in language learning // Procedia Social and Behavioral Sciences. — 2010. P. 2712-2716. doi:10.1016/j.sbspro.2010.03.401.

8 Bergmann J., Sams A. Flip your Classroom. Reach Every Student in Every Class Every Day. U.S.A.: International Society for Technology in Education. - 2012.

9 Симонова М.В. «Перевернутый класс» на занятиях по испанскому языку в вузе / М.В. Симонова // Актуальные аспекты фундаментальных и прикладных исследований: сб. науч. тр. - Орёл, 2016. - С. 48-55.

10 Robert Talbert. Flipped learning: a guide for higher education Faculty. — 2017.

11 Beaten M., Kyndt E., Struyven K., Dochy F. Using student-centred learning environments to stimulate deep approaches to learning: Factors encouraging or discouraging their effectiveness // Educaional research review. — 2010. — Vol. 5, № 3. — P.243260. https://doi.org/10.1016/j.edurev.2010.06.001.

12 Matukhin D., Bolgova D. Learner-centered Approach in Teaching Foreign Language: Psychological and Pedagogical Conditions // Procedia - Social and behavioral sciences. - 2015. - Vol. 206. - P. 148-155. https://doi.org/10.1016/j.sbspro.2015.10.044.

13 YungweiHao. Middle school students' flipped learning readiness in foreign language classrooms: Exploring its relationship with personal characteristics and individual circumstances // Computers in human behavior. — 2016. - Vol. 59. — P. 295-303. https://doi.org/10.1016/j.chb.2016.01.031.

14 Пургина Е.И. Методологические подходы в современном образовании и педагогической науке: учеб. пос. / Е.И. Пургина. — Екатеринбург: Урал. гос. пед. ун-т, 2015. — 275. — С. 9-11.

15 Лернер И.Я. Дидактические основы методов обучения / И.Я. Лернер. - М., 1981.

16 Педагогика / Под ред. Ю.К. Бабанского. - 2-е изд. - М., 1988. - С. 385.

17 Харламов И.Ф. Педагогика / И.Ф. Харламов. — 2-е изд. - М., 1990. — С. 194, 195.

18 Hamdan, N., McKnight, P. A review of flipped learning. Flipping Learning Network. — 2013. DOI:10.4236/ce.

19 Basal, A. The implementation of a flipped classroom in foreign language teaching //Turkish Online Journal of Distance Education. - 2015. - Vol. 16(4). — P. 28-37. http://dx.doi.org/10.17718/tojde.72185.

20 Evseeva, A., \& Solozhenko, A. Use of flipped classroom technology in language learning // Procedia Social and Behavioral Sciences. — 2015. -P. 205-209. https://doi.org/10.1016/j.sbspro.2015.10.006.

21 Soliman, N.A. Teaching English for academic purposes via the flipped learning approach // Procedia-Social and Behavioral Sciences. - 2016. -P. 122-129.

22 Melendez L., Sarah I. Application of the flipped classroom methodology in a virtual platform for teaching English language grammar in level B1 //RevistaPublicndo. - 2017. - Vol. 4, № 12 (1). -P. 236-246.

23 Santikarn, B., \&Wichadee, S. (2018). Flipping the Classroom for English Language Learners: A Study of Learning Performance and Perceptions // International Journal of Emerging Technologies in Learning (IJET). — 2018. — № 13(09). -P. $123-135$. https://doi.org/10.3991/ijet.v13i09.7792.

24 Fauzan, A., \&Ngabut, M. N. EFL students' perception on flipped learning in writing class // Journal on English as a Foreign Language. — 2018. — № 8(2). -P. 115-129. https://doi.org/10.23971/ jefl.v8i2.792.

\title{
Т.С. Ударцева, К. Де Веро, Н.В. Дружинина
}

\section{Шет тілін дайындауда төңкерілген оқыту әдісін қолданудың әлемдік тәжірибесін бейімдеу жолдары}

\begin{abstract}
Мақалада авторлар төңкерілген оқыту әдісінің тұжырымдамасын, оның ерекшеліктері мен компоненттерін қарастырған. Төңкерілген оқыту (бұдан әрі ТО) - бұл дәстүрлі білім беру жүйесін трансформациялауға бағытталған педагогикалық әдіс. Бұл әдіс топтық және жеке жұмыс кезінде орындалатын қызмет түрлерін топтастыруды білдіреді (бұрын сабақта орындалған іс-әрекетті енді білім алушылар сабақтан тыс уақытта орындайды). Отандық білім беру жүйесінде ТО әдісін қолданудың жеткіліксіз жариялануына байланысты, авторлар әлемнің 5 елі, оның ішінде: Ресей, Египет, Эквадор, Таиланд және Индонезияның жоғары оку орындарында ағылшын тілін шет тілі ретінде оқыту үрдісінде осы әдісті қолданудың тиімділігін зерттеуге көңіл бөлді. Зерттеу үшін университеттерді іріктеу мына критерийлер бойынша жүргізілді: оку деңгейі, шет тілін шетел тілі ретінде оқу, төңкерілген оқыту элементі мен курс соңында кері байланыстың болуы. Зерттеу талдауы көрсеткендей, барлық университеттерде білім беру үрдісінде ТО-ды қолдануға деген қатысушылардың оң көзқарасы байқалады. Негізгі жағымды жақтардың ішінде мыналар: тілді меңгеру деңгейінің жақсаруы, студенттердің өз оқуын ұйымдастырудағы дербестік деңгейінің артуы,
\end{abstract}


білім беру үрдісінде цифрлық технологияларды толық енгізу мүмкіндігі. Авторлар шетелдік университеттердің тәжірибесіне жүргізілген талдау нәтижелері ретінде отандық ЖОО-да шет тілін оқыту процесіне ТО әдісін енгізу үшін мүмкіндіктер, қиындықтармен қауіптердің болуын анықтауға мүмкіндік беретін SWOT-талдауын жүргізді.

Кілт сөздер: шетел тілі, төңкерілген оқыту, жеке кеңістік, топтық кеңістік, SWOT талдау, цифрлық платформа, белсенді оқыту әдістері, дәстүрлі оқыту жүйесі.

\title{
Т.С. Ударцева, К. Де Веро, Н.В. Дружинина
Пути адаптации мирового опыта использования метода перевернутого обучения в иноязычной подготовке

\begin{abstract}
В статье рассмотрено понятие метода перевернутого обучения, изучены его особенности и составляющие компоненты. Перевернутое обучение (далее ПО) - это педагогический метод, направленный на трансформацию традиционной системы образования. Данный метод подразумевает ротацию видов деятельности, выполняемых в групповом и индивидуальном пространстве (то, что раньше выполнялось на занятии, теперь обучающиеся выполняют вне занятий). В связи с недостаточной освещенностью применения метода ПО в отечественной системе образования авторы сосредоточили свое внимание на изучении эффективности его применения в процессе преподавания английского языка как иностранного в вузах пяти стран мира: Россия, Египет, Эквадор, Таиланд и Индонезия. Отбор вузов для исследования проводился по таким критериям, как уровень обучения, изучение иностранного языка как иностранного, наличие элемента перевёрнутого обучения, наличие обратной связи по окончанию курса. Как показал анализ, во всех университетах отмечается положительное отношение всех участников образовательного процесса к применению ПО. Среди основных положительных моментов отмечается следующее: улучшение уровня владения языком, увеличение уровня самостоятельности студентов в организации своего обучения, возможности полноценного внедрения цифровых технологий в образовательный процесс. В качестве результатов проведенного анализа опыта зарубежных университетов авторами был проведен SWOT-анализ, позволяющий определить наличие возможностей, трудностей и угроз для внедрения метода ПО в процесс изучения иностранного языка в отечественном вузе.
\end{abstract}

Ключевые слова: иностранный язык, перевёрнутое обучение, индивидуальное пространство, групповое пространство, SWOT-анализ, цифровая платформа, активные методы обучения, традиционная система обучения.

\section{References}

1 Gluchmanova M. (2015). Application of e-learning in foreign language teaching at the technical university. Social and Behavioral Sciences, 3144-3149. DOI: https://doi.org/10.1016/j.sbspro.2015.01.1053.

2 Fischer, G. (2000). Lifelong learning - More than Training. Journal of Interactive Learning Research, 11, 3(4),265-294.

3 Babic Z. (2016). Exploring ESP syllabi: some implications for further pedagogical considerations.ZbornikInstitutazaPedagoskaIstrazivanja, Vol. 48, issue 1,164-179. DOI: http://dx.doi.org/10.2298/ZIPI1601164B.

4 Fredy Geovanni Escobar Fandino, Luz Dary Munoz, Angela Juliette Silva Velandia. (2019). Motivation and E-Learning English as a foreign language: A qualitative study. Heliyon, № 5,1-7. DOI: https://doi.org/10.1016/j.heliyon.2019.e02394.

5 Bradac V., Walek B. (2017). A comprehensive adaptive system for e-learning of foreign languages. Expert system with applications, Vol. 90, 414-426. DOI: https://doi.org/10.1016/j.eswa.2017.08.019.

6 Hubackova S., Ruzickova M. Experience in foreign language teaching with ICT support.Procedia computer science, Vol. 3, 243-247. DOI: https://doi.org/10.1016/j.procs.2010.12.041.

7 Dettori G., Lupi V. ICT and new methodologies in language learning // Procedia Social and Behavioral Sciences. — 2010. P. 2712-2716. doi:10.1016/j.sbspro.2010.03.401.

8 Bergmann J., Sams A (2012). Flip your Classroom. Reach Every Student in Every Class Every Day. U.S.A.: International Society for Technology in Education.

9 Simonova, M.V. (2016). «Perevernutyi klass» na zaniatiiakh po ispanskomu yazyku v vuze [«Flipped classroom» at Spanish language lessons in higher educational establishment]. Aktualnye aspekty fundamentalnykh $i$ prikladnykh issledovanii: sbornik nauchnykh trudov - Topical issues of fundamental and applied research: proceeding book, Orel, 48-55 [in Russian].

10 Robert Talbert (2017). Flipped learning: a guide for higher education Faculty.

11 Beaten M., Kyndt E., Struyven K., Dochy F. (2010). Using student-centred learning environments to stimulate deep approaches to learning: Factors encouraging or discouraging their effectiveness. Educaional research review, Vol. 5, № 3, $243-260$. DOI: https://doi.org/10.1016/j.edurev.2010.06.001.

12 Matukhin D., Bolgova D. (2015). Learner-centered Approach in Teaching Foreign Language: Psychological and Pedagogical Conditions. Procedia - Social and behavioral sciences, Vol. 206, 148-155. DOI: https://doi.org/10.1016/j.sbspro.2015.10.044. 
13 Yungwei Hao. (2016). Middle school students' flipped learning readiness in foreign language classrooms: Exploring its relationship with personal characteristics and individual circumstances. Computers in human behavior, Vol. 59, 295-303. DOI: https://doi.org/10.1016/j.chb.2016.01.031.

14 Purgina, E.I. (2015). Metodolohicheskie podkhody v sovremennom obrazovanii i pedahohicheskoi nauke [Methodological approaches in modern education and pedagogical sciences]. Yekaterinburh, 9-11 [in Russian].

15 Lerner, I.Ya. (1981). Didakticheskie osnovy metodov obucheniia [Didactical foundations of teaching methods]. Moscow [in Russian].

16 Babanskiy, Yu.K. (1988). Pedahohika [Pedagogy]. Edition 2. Moscow, 385 [in Russian]

17 Kharlamov, I.F. (1990). Pedahohika [Pedagogy]. Edition 2. Moscow, 194, 195 [in Russian].

18 Hamdan, N., McKnight, P. (2013). A review of flipped learning. Flipping Learning Network. DOI: 10.4236/ce.

19 Basal, A. (2015). The implementation of a flipped classroom in foreign language teaching. Turkish Online Journal of Distance Education, 16(4), 28-37. DOI: http://dx.doi.org/10.17718/tojde.72185.

20 Evseeva, A., \&Solozhenko, A. (2015). Use of flipped classroom technology in language learning. Procedia Social and Behavioral Sciences, 206, 205-209. DOI: https://doi.org/10.1016/j.sbspro.2015.10.006.

21 Soliman, N. A. (2016). Teaching English for academic purposes via the flipped learning approach. ProcediaSocialandBehavioralSciences, 232, 122-129.

22 Melendez L., Sarah I. (2017). Application of the flipped classroom methodology in a virtual platform for teaching English language grammar in level B1.RevistaPublicndo, Vol. 4, № 12 (1), 236-246.

23 Santikarn, B., \&Wichadee, S. (2018). Flipping the Classroom for English Language Learners: A Study of Learning Performance and Perceptions. International Journal of Emerging Technologies in Learning (IJET), 13(09), 123-135. DOI: https://doi.org/10.3991/ijet.v13i09.7792.

24 Fauzan, A., \&Ngabut, M. N. (2018). EFL students' perception on flipped learning in writing class. Journal on English as a Foreign Language, 8(2), 115. DOI: https://doi.org/10.23971/ jefl.v8i2.792. 